\title{
DAMPAK PERATURAN MENTERI PERDAGANGAN REPUBLIK INDONESIA NOMOR 84 TAHUN 2019 TENTANG KETENTUAN IMPOR LIMBAH NONBAHAN BERBAHAYA DAN BERACUN SEBAGAI BAHAN BAKU INDUSTRI TERHADAP EKSPOR KERTAS INDONESIA (STUDI KASUS PT XYZ)
}

\author{
Sheilda \\ Program Studi Magister Manajemen Universitas Tarumanagara \\ sheilda96@hotmail.com \\ Sawidji Widoatmodjo \\ Program Studi Magister Manajemen Universitas Tarumanagara
}

Masuk : 07-12-2020, revisi : 22-12-2020, diterima untuk diterbitkan : 23-12-2020

\begin{abstract}
The purpose of this research is to determine the impact of the Regulation of the Minister of Trade of the Republic of Indonesia Number 84 of 2019 concerning the import of hazardous and toxic non-hazardous waste as industrial raw materials on the export of Brown Paper PT XYZ. This research uses statistical methods on SPSS namely Bivariate Correlation, Simple Regression Analysis, and Wilcoxon Signed-Rank Test for Dependent Population as the main approach to conducting research. The results determine that there is no significant correlation between imported waste paper and the export volume of PT XYZ. The result also determine Imported waste paper has no significant impact on machine consumption, and machine consumption has no significant impact on the exported paper volume of PT XYZ. The main results of this result determine that there is no significant difference in the paper export volume of PT XYZ before and after the enactment of PERMENDAG number 84 of 2019.

Keywords: Export, PERMENDAG 84, Old Corrugated Containers, Brown Paper, Wilcoxon Signed-Rank Test for Dependent Population

Abstrak: Tujuan penelitian adalah mengetahui dampak Peraturan Menteri Perdagangan Republik Indonesia Nomor 84 Tahun 2019 tentang ketentuan impor limbah nonbahan berbahaya dan beracun sebagai bahan baku industri terhadap ekspor Brown Paper PT XYZ. Penelitian ini menggunakan metode statistik yaitu Bivariate Correlation, Simple Regression Analysis dan Wilcoxon Signed-Rank Test for Dependent Population sebagai metode pendekatan utama untuk melakukan penelitian. Hasil yang didapatkan menunjukkan bahwa tidak ada korelasi yang signifikan antara wastepaper impor dan volume ekspor PT XYZ. Hasil penelitian juga menunjukkan bahwa wastepaper impor tidak memiliki pengaruh yang signifikan terhadap konsumsi mesin, dan konsumsi mesin tidak berpengaruh secara signifikan terhadap volume ekspor PT XYZ. Hasil yang diperoleh adalah tidak terdapat perbedaan yang signifikan data volume ekspor kertas PT XYZ sebelum dan sesudah diberlakukannya PERMENDAG nomor 84 tahun 2019. Berdasarkan hasil penelitian tersebut beberapa rekomendasi bagi perusahaan.
\end{abstract}

Kata Kunci: Ekspor, PERMENDAG 84, Old Corrugated Containers, Brown Paper, Wilcoxon Signed-Rank Test for Dependent Population

\section{PENDAHULUAN}

Berdasarkan data Badan Pusat Statistik, ekspor kertas juga berada di urutan ke-9 dilihat dari nilai dari keseluruhan ekspor yang dilakukan Indonesia. Selain itu, Indonesia juga sudah dikenal sebagai penghasil kertas terbaik di dunia. Hal ini membuat permintaan selalu naik di pasar internasional. Asosiasi Pulp dan Kertas Indonesia (APKI) juga mencatat Indonesia merupakan negara pada peringkat keenam sebagai produsen kertas terbesar di dunia dan 
menduduki peringkat keempat di Asia (Rini, 2019). Pencapaian ini tentunya didukung oleh kapasitas produksi industri kertas Indonesia yang tercatat sebesar 16 juta ton per tahun, dengan jumlah perusahaan kertas dan pulp mencapai 62 perusahaan. Walaupun pasar menjanjikan, itu belum tentu bisa Indonesia penuhi karena berbagai kendala, khususnya di sektor penghasil kertas kemasan yang berbahan baku kertas bekas.

Seperti yang dikutip oleh Laoli (2020), Wakil Menteri Perdagangan (Wamendag) Jerry Sambuaga melihat ada dua masalah yang sangat penting dan harus segera diselesaikan setelah melakukan kunjungan dan pelepasan ekspor. Pertama, kepastian regulasi mengenai pasokan bahan baku dalam industri kertas kemasan. Industri kertas kemasan memerlukan pasokan daur ulang kertas yang berkelanjutan dan mudah didapat karena lebih dari 50 persennya merupakan kertas daur ulang. Pasokan domestik Indonesia hanya mampu memenuhi sekitar separuh dari kebutuhan bahan baku yang dibutuhkan, sisanya harus mengandalkan impor. Yang kedua adalah mengenai ketentuan Bukti Eksportir Terdaftar (BET) yang direncanakan mulai berlaku 1 Oktober 2020. Ketentuan ini, menurut Wamendag perlu sebagai langkah antisipasi jika ada ketidaksesuaian dalam proses impor. BET sendiri adalah aturan yang menyatakan bahwa eksportir bahan baku kertas harus terdaftar dan diverifikasi oleh perwakilan Indonesia di luar negeri yaitu Kedutaan Besar RI. Dengan kapasitas produksi sebesar Indonesia, ketersediaan bahan baku yang diperlukan oleh industri tidak dapat diperoleh sepenuhnya dari dalam negeri sehingga diperlukan impor limbah Non B3 sebagai bahan baku industri.

Industri kertas membutuhkan sampah kertas (wastepaper) untuk diolah kembali menjadi kertas baru. Berdasarkan data Jambeck (2015) yang dikutip oleh Wahyuni (2016), Indonesia menduduki peringkat kedua penghasil sampah plastik yang mencapai 189,2 juta ton per tahun. Selain, sampah yang dihasilkan sendiri, Indonesia juga menjadi negara tujuan ekspor sampah. Perusahaan diperbolehkan untuk mengimpor limbah non-B3 untuk memenuhi kebutuhan bahan baku industri serbagaimana yang telah diatur dalam Peraturan Menteri Perdagangan Nomor 31 Tahun 2016 tentang Ketentuan Impor Limbah NonBahan Beracun Berbahaya. Peraturan ini membatasi bahwa limbah non-B3 yang dapat diimpor tidak berasal dari kegiatan landfill atau tidak berupa sampah, tidak terkontaminasi B3 dan/atau limbah B3, serta tidak tercampur limbah lainnya.

Importir juga harus memiliki persetujuan impor (PI) dari menteri perdagangan yang bisa didapat setelah memiliki rekomendasi dari Direktur Jenderal Pengelolaan Sampah, Limbah, dan Bahan Berbahaya dan Beracun KLHK serta rekomendasi dari Direktur Jenderal Kimia dan Aneka Kementerian Perindustrian. Limbah non-B3 yang akan dikapalkan juga harus mendapatkan verifikasi surveyor di negara muat. Penggunaan wastepaper sebagai bahan baku menjadi sorotan lembaga Ecological Observation and Wet Conservation (Ecoton) yang menemukan masuknya wastepaper impor disertai dengan sampah plastik. Jenis sampah kertas dengan kode HS 47079000 diduga menjadi jenis wastepaper yang dengan mudah bisa disusupi sampah plastik karena merupakan jenis sampah kertas scrap campuran atau mixed paper. Dengan adanya penemuan Ecoton ini, maka peraturan mengenai Impor Limbah Non B3 Sebagai Bahan Baku Industri perlu diatur sedemikian rupa agar dalam realisasinya tidak menimbulkan kerusakan atau pencemaran lingkungan hidup.

Direktur Eksekutif Asosiasi Pulp dan Kertas Indonesia (APKI) Liana Bratasida mengatakan, sebagai importir wastepaper, APKI tidak menginginkan keberadaan kandungan bahan lain selain kertas (Damayanti, 2019). Bahan lain yang dimaksud adalah plastik, logam, tekstil, dan bahan lainnya. Namun dikarenakan wastepaper merupakan hasil pengumpulan atau koleksi yang berasal dari berbagai tempat, maka keberadaan bahan lain selain kertas tersebut sulit untuk dihindari. Untuk memonitor jumlah kandungan lain selain kertas, impor wastepaper disesuaikan dengan standar ISRI (Institute of Scrap Recycling Industries). Warmendag mengatakan ada perbedaan persepsi antara pengusaha dengan pemerintah. Pemerintah menginginkan adanya homogenitas (kemurnian) barang yang diimpor Indonesia, tidak terkecuali bahan baku kertas. Ini diatur Dalam Peraturan Menteri Perdagangan Republik 
Indonesia Nomor 84 Tahun 2019 Tentang Ketentuan Impor Limbah Nonbahan Berbahaya Dan Beracun Sebagai Bahan Baku Industri untuk memudahkan proses dalam importasi barang. Tetapi pada kenyataannya, pengusaha merasa bahwa peraturan itu justru membuat industri kertas daur ulang di Indonesia menjadi kurang kompetitif. Diawali dengan kertas campuran (mix paper) yang harganya sangat ekonomis justru dilarang masuk ke Indonesia karena tidak homogen (murni), negara-negara pesaing seperti Vietnam dan Thailand mix paper justru diperbolehkan.

Permerintah terus memperbaharui Peraturan Menteri Perdagangan (PERMENDAG) Nomor 84 Tahun 2019 tentang Ketentuan Impor Limbah NonBahan Berbahaya dan Beracun sebagai bahan baku industri demi mencapai ketentuan yang terbaik bagi industri. Sampai saat tesis ini ditulis, PERMENDAG 84 tahun 2019 sudah melewati 3 kali perubahan. Berbagai perubahan yang tidak pasti ini tentunya menjadi hambatan bagi pengusaha. Pemerintah juga sering dipandang tidak konsisten dan cenderung tidak tegas. Pemasok kesulitan untuk mengirimkan barangnya ke Indonesia karena terhalang regulasi-regulasi yang mengejutkan. Bukan hanya kesulitan, pemasok bahkan harus menghentikan seluruh kegiatan untuk mengirim barang ke Indonesia, mulai dari menghentikan inspeksi hingga membatalkan kapal. Tidak terkecuali PT. XYZ. Pemasok imported wastepaper PT XYZ datang dari berbagai negara, tidak ada satupun negara yang dimudahkan oleh PERMENDAG Nomor 84 ini. Pemasok takut untuk mengekspor ke Indonesia, terlebih lagi di awal PERMENDAG ini diberlakukan. Eksportir diharuskan melakukan inspeksi berulang kali yang tentu saja menghabiskan biaya yang tidak sedikit guna mematuhi isi dari PERMENDAG Nomor 84 tersebut.

\section{Tujuan Penelitian}

Penelitian ini memiliki tujuan untuk melihat perbedaan rata-rata masing-masing volume impor wastepaper dan ekspor kertas sebelum dan sesudah adanya PERMENDAG nomor 84 tahun 2019 berserta dengan perubahaannya yaitu PERMENDAG Nomor 92 Tahun 2019, PERMENDAG Nomor 58 Tahun 2020 dan PERMENDAG Nomor 83 Tahun 2020. Kemudian peneliti juga ingin mengetahui apakah terdapat pengaruh yang signifikan antara volume impor wastepaper dengan volume ekspor kertas PT XYZ setelah adanya PERMENDAG nomor 84 tahun 2019.

\section{TINJAUAN PUSTAKA}

Fukumoto dan Kinugasa (2017) menemukan beberapa faktor yang dapat menjelaskan trade policy suatu negara. Faktor-faktor tersebut antara lain ukuran negara, posisi ekonomi negara, besarnya arus fdi di negara tersebut, nilai tukar efektif riil, kualitas kelembagaan, ketentuan pergerakan perdagangan dan struktur penuaan populasi. Krugman (1986) menyatakan bahwa sebuah negara dapat melakukan intervensi pada kebijakan investasi dan perdagangan internasional untuk kepentingan nasional yang berlawanan dengan kebijakan perdagangan. Analysis et al., (1987) juga membahas peran kebijakan perdagangan dalam mempengaruhi keputusan perusahaan dalam harga, kuantitas dan kualitas produknya.

Dalam melakukan penelitian ini, peneliti menggunakan beberapa tinjauan sebagai referensi dari artikel-artikel terdahulu yang pernah dilakukan oleh peneliti lain. Yang pertama adalah penelitian yang dilakukan oleh Barbosa et al., (2016). Penelitian ini dilaksanakan untuk mengetahui faktor apa saja yang mempengaruhi ekspor. Maka dari itu, variabel yang digunakan di dalam penelitian ini adalah Production Resources dan Export. Setelah diolah, penelitian ini membuktikan bahwa variabel Production Resources memiliki hubungan yang positif dengan Export. Penelitian kedua yang peneliti ambil adalah penelitian yang ditulis oleh Yakusheva et al. (2017). Tujuan dari penelitian ini adalah untuk mengetahui bagaimana cara menanggulangi kekurangan raw resources yang berperan penting dalam sebuah industri. Ada dua variabel yang diangkat yaitu Raw Resources dan Production Capacity. Hasil dari penelitian ini menunjukkan bahwa Production Capacity berkurang dikarenakan menurunnya Raw Resources, maka dapat disimpulkan bahwa Production Capacity dipengaruhi secara searah oleh Raw Resource. 
Penelitian ketiga adalah penelitian yang dilakukan oleh Cahyadi dan Sukarsa (2015) dengan variabel penelitian produksi dan ekspor kertas menyatakan bahwa secara parsial produksi berpengaruh positif dan signifikan terhadap ekspor kertas. Mereka juga menyimpulkan bahwa produksi merupakan variabel yang paling berpengaruh terhadap ekspor kertas Indonesia.

Penelitian keempat dilakukan oleh Analysis et al., (1987) dengan variabel penelitian kebijakan perdagangan dan kuantitas membahas peran kebijakan perdagangan dalam mempengaruhi keputusan perusahaan dalam harga, kuantitas dan kualitas produknya. Hasil dari penelitian ini menunjukkan bahwa menetapkan impor dengan persyaratan kualitas minimum menghambat kesejahteraan nasional. Penelitian kelima yang dilakukan oleh Ogura (2020) dengan variabel kapasitas produksi dan dua jenis kebijakan energi terbarukan (RE), feed-in tariff (FIT) dan standar portofolio terbarukan (RPS), untuk ekspor di negara-negara OECD dan BRICS, menunjukkan bahwa ada pengaruh positif dari kebijakan dan kapasitas produksi terhadap kinerja ekspor. Dalam penelitiannya, Lubis (2010) menyatakan bahwa penawaran ekspor cenderung inelastis terhadap peruabahan impor bahan baku, dalam artian kenaikan satu persen impor bahan baku menyebabkan kenaikan pada penawaran ekspor. Disimpulkan bahwa impor bahan baku berpengaruh dalam meningkatkan volume ekspor. Sedangkan Hayakawa et al., (2020) mengemukakan bahwa suatu negara yang menurunkan tarif impornya dapat mengalami peningkatan ekspor maupun impor. Penelitian Erduman et al., (2020) menunjukkan bahwa pada industri manufaktur, ketergantungan impor meningkat untuk ekspor, tetapi tetap relatif stabil untuk produksi dari waktu ke waktu.

H1: Terdapat hubungan yang signifikan antara volume impor wastepaper dan volume ekspor kertas

Seperti penelitian Yakusheva et al., (2017) yang menemukan bahwa Kapasitas Produksi dipengaruhi secara searah oleh Bahan Baku. Hasil serupa juga ditemukan oleh Istanti dan Karmini (2016) bahwa bahan baku berpengaruh positif terhadap produksi.

\section{H2: Terdapat pengaruh impor wastepaper terhadap konsumsi mesin}

Assauri (2018) mengatakan bahwa produksi adalah kegiatan yang merubah input menjadi output yang mencakup semua kegiatan yang menghasilkan barang atau jasa. Proses produksi yang baik akan menghasilkan hasil produksi dengan kualitas yang baik pula. Komalasari (2009) menyatakan bahwa ada hubungan yang searah antara volume produksi dan volume ekspor, dimana jika produksi meningkat maka volume ekspor juga akan meningkat, begitu pula sebaliknya. Hasil serupa juga ditemukan oleh Simanjuntak et al., (2017) dalam penelitiannya bahwa variabel produksi berpengaruh positif terhadap volume ekspor. Mejaya et al., (2016) juga menyimpulkan bahwa variabel produksi berpengaruh positif namun secara parsial tidak berpengaruh signifikan terhadap volume ekspor. Istanti dan Karmini (2016) juga menemukan bahwa volume produksi juga berpengaruh positif terhadap Ekspor.

H3: Terdapat pengaruh yang signifikan antara konsumsi mesin terhadap ekspor kertas

Dalam penelitiannya Cahyadi dan Sukarsa (2015) menyatakan bahwa terdapat perbedaan jumlah ekspor kertas jika terjadi sesuatu dengan negara eksportir. Du dan Li (2020) menemukan dalam penelitian mereka bahwa regulasi lingkungan dapat membatasi margin yang ekstensif dan intensif ekspor

H4: Terdapat perbedaan yang signifikan antara data volume ekspor kertas sebelum dan sesudah diberlakukannya PERMENDAG nomor 84 tahun 2019

\section{METODOLOGI PENELITIAN}

Penelitian ini menggunakan jenis data kuantitatif, sumber data sekunder dengan waktu penelitian cross sectional. Metode pengumpulan data yang digunakan adalah penelitian kepustakaan, dokumen historis, wawancara dan kuesioner. Sedangkan variabel yang peneliti angkat yaitu Impor wastepaper, Konsumsi Mesin dan Ekspor Kertas. Berikut adalah definisi operasionalnya: 
Tabel 1

Definisi Operasional Variabel

\begin{tabular}{|c|c|c|c|}
\hline Variabel & Definisi Operasional & Pengukuran & Skala \\
\hline $\begin{array}{c}\text { Impor Waste Paper } \\
\text { (Buy) }\end{array}$ & Volume impor bulanan waste paper sebagai bahan baku \\
produksi & $\begin{array}{c}\text { Data diambil dari data } \\
\text { perusahaan }\end{array}$ & Rasio \\
\hline $\begin{array}{c}\text { Konsumsi Mesin } \\
\text { (Ussage })\end{array}$ & $\begin{array}{c}\text { Volume bahan baku bulanan PM14 yang digunakan di dalam } \\
\text { produksi }\end{array}$ & $\begin{array}{c}\text { Data diambil dari data } \\
\text { perusahaan }\end{array}$ & Rasio \\
\hline $\begin{array}{c}\text { Ekspor Kertas } \\
\text { (Sales })\end{array}$ & $\begin{array}{c}\text { Volume ekspor Brown Paper bulanan yang dihasilkan dari } \\
\text { produksi bahan baku impor limbah }\end{array}$ & $\begin{array}{c}\text { Data diambil dari data } \\
\text { perusahaan }\end{array}$ & Rasio \\
\hline
\end{tabular}

Sumber: Peneliti (2019)

Peneliti menggunakan SPSS untuk mengolah data data penjualan Brown Paper, konsumsi mesin untuk produksi Brown Paper dan pembelian wastepaper. Metode yang digunakan adalah Uji Korelasi Bivariat, Uji Regresi Sederhana dan Uji Wilcoxon Signed-Rank Test for Dependent Population.

\section{HASIL DAN KESIMPULAN}

Berdasarkan hasil pengolahan data perusahaan dengan menggunakan SPSS, maka peneliti dapat menarik beberapa kesimpulan sebagai jawaban untuk pertanyaan penelitian ini yaitu: (1) Tidak terdapat hubungan yang signifikan antara volume impor wastepaper dan volume ekspor kertas PT XYZ. Maka dari itu berdasarkan hasil wawancara dengan perwakilan perusahaan peneliti mendapatkan informasi bahwa penjualan kertas bulan berjalan tidak mengandalkan volume impor bahan baku di bulan yang sama, melainkan sudah memiliki stok dari bulan-bulan sebelumnya. Hal ini didukung dengan adanya data impor dimulai dari bulan Agustus tahun 2018 dan produksi pertama dilakukan pada bulan Januari 2020. (2) Tidak terdapat pengaruh yang signifikan antara impor wastepaper terhadap konsumsi mesin. Menurut perwakilan perusahaan, bahwa produksi akan tetap berjalan walaupun pembelian wastepaper pada bulan tersebut menurun atau bahkan tidak membeli. Jika memang volume pembelian turun, maka volume yang akan dikonsumsi oleh mesin produksi adalah volume yang menjadi safety stock pabrik, maka tidak berpengaruh signifikan karena selama ini stok masih bisa memenuhi volume yang dibutuhkan untuk produksi. (3) Tidak pengaruh yang signifikan antara konsumsi mesin terhadap ekspor kertas PT XYZ. Dapat dilihat berdasarkan data yang diberikan perusahaan bahwa produksi dimulai dari bulan Januari 2019 namun ekspor dengan jumlah kecil baru dilakukan pada bulan Februari 2019. Ini menunjukkan bahwa setelah mesin mulai berjalan pada bulan Januari maka barang hasil produksi disimpan terlebih dahulu dan dijual dikemudian hari sehingga membuat volume penjualan tidak terpengaruh kepada performa mesin. Perwakilan perusahaan mengatakan ini harus dilakukan demikian karena setiap bulan Desember mesin akan shutdown sehingga dibutuhkan stok untuk melakukan penjualan. (4) Tidak terdapat perbedaan yang signifikan data volume ekspor kertas PT XYZ sebelum dan sesudah diberlakukannya PERMENDAG nomor 84 tahun 2019. Perwakilan perusahaan menginformasikan bahwa ketidakjelasan peraturan yang ada saat ini mengenai impor limbah sebagai bahan baku industri membuat PT XYZ untuk mencari alternatif lain. Seperti dimulai tahun 2020 ini, perusahaan mulai menggunakan Deinked Pulp (DIP) yang diproduksi di mesin lain serta menggunakan bahan-bahan yang bisa didapatkan dengan Cuma-Cuma seperti Fibre Recovery Pulp, Broke dan Sludge untuk memenuhi kebutuhan ekspor dan menekan production cost. Ini menyebabkan adanya PERMENDAG nomor 84 tahun 2019 dan beberapa penyempurnaannya tidak membuat volume ekspor perusahaan berubah secara signifikan.

\section{DAFTAR PUSTAKA}

Analysis, A. W., Das, S. P., \& Donnenfeld, S. (1987). Trade policy and its impact on quality of imports. Journal of International Economics, 23(1-2), 77-95.

https://doi.org/10.1016/S0022-1996(87)80006-5

Assauri, S. (2018). Manajemen operasi produksi (3rd ed.). Lembar Penerbitan Fakultas Ekonomi Universitas Indonesia. 
Barbosa, D. M. E., Ayala, A. H., \& Sandoval, A. A. (2016). The Colombian pharmaceutical industry: Factors affecting export. European Journal of Management and Business Economics, 25(2), 39-46. https://doi.org/10.1016/j.redee.2015.10.004

Cahyadi, N. M. A. K., \& Sukarsa, M. (2015). Faktor-faktor yang memengaruhi ekspor kertas dan barang berbahan kertas di Indonesia periode tahun 1988-2012. E-Jurnal EP Unud, 4(1), 63-70. https://ojs.unud.ac.id/index.php/eep/article/view/11005/8171

Damayanti, I. (2019). APKI: Tak ada penyalahgunaan izin impor Kertas. Republika.Co.Id. https://republika.co.id/berita/ptcfe8383/apki-tak-ada-penyalahgunaan-izin-impor-kertas

Du, W., \& Li, M. (2020). Influence of environmental regulation on promoting the low-carbon transformation of China's foreign trade: Based on the dual margin of export enterprise. Journal of Cleaner Production, 244. https://doi.org/10.1016/j.jclepro.2019.118687

Erduman, Y., Eren, O., \& Gül, S. (2020). Import content of Turkish production and exports: A sectoral analysis. Central Bank Review, 20(4), 155-168. https://doi.org/10.1016/j.cbrev.2020.07.001

Fukumoto, Y., \& Kinugasa, T. (2017). Age structure and trade openness: An empirical investigation. World Economy, 40(6), 1247-1263. https://doi.org/10.1111/twec.12464

Hayakawa, K., Ishikawa, J., \& Tarui, N. (2020). What goes around comes around: Exportenhancing effects of import-tariff reductions. Journal of International Economics, 126. https://doi.org/10.1016/j.jinteco.2020.103362

Istanti, Y., \& Karmini, N. L. (2016). Pengaruh bahan baku, tenaga kerja, dan investasi terhadap produksi serta ekspor keramik di Kabupaten Tabanan. E-Jurnal EP Unud, 5(2), 276-297. https://ojs.unud.ac.id/index.php/eep/article/view/17592/12970

Komalasari, I. (2009). Analisis faktor-faktor yang mempengaruhi penawaran ekspor biji kakao Indonesia. Institut Pertanian Bogor.

Krugman, P. R. (1986). Strategic trade policy and the new international economics. The MIT Press.

Laoli, N. (2020). Kelangsungan pasokan bahan baku ekspor kertas daur ulang jadi perhatian pemerintah. Kontan.co.id. https://nasional.kontan.co.id/news/kelangsungan-pasokanbahan-baku-ekspor-kertas-daur-ulang-jadi-perhatian-pemerintah

Lubis, A. D. (2010). Analisis faktor yang mempengaruhi kinerja ekspor Indonesia. Buletin Ilmiah Litbang Perdagangan, 4(1), 1-13. https://doi.org/10.30908/bilp.v4i1.144

Mejaya, A., Fanani, D., \& Mawardi, M. (2016). Pengaruh produksi, harga internasional, dan nilai tukar terhadap volume ekspor (Studi pada ekspor Global Teh Indonesia periode tahun 2010-2013). Jurnal Administrasi Bisnis (JAB), 35(2), 20-29.

http://administrasibisnis.studentjournal.ub.ac.id/index.php/jab/article/view/1364

Ogura, Y. (2020). Policy as a "porter" of RE component export or import? Evidence from PV/wind energy in OECD and BRICS. Energy Economics, 86. https://doi.org/10.1016/j.eneco.2019.104630

Rini, A. S. (2019). Industri pulp dan kertas Indonesia masuk 10 besar dunia. Bisnis.com. https://ekonomi.bisnis.com/read/20190127/257/882862/industri-pulp-dan-kertasindonesia-masuk-10-besar-dunia

Simanjuntak, P., Arifin, Z., \& Mawardi, M. (2017). Pengaruh produksi, harga internasional dan nilai tukar Rupiah terhadap volume ekspor rumput laut Indonesia (Studi pada tahun 2009-2014). Jurnal Administrasi Bisnis S1 Universitas Brawijaya, 50(3), 163-171. http://administrasibisnis.studentjournal.ub.ac.id/index.php/jab/article/view/2018/2410

Wahyuni, T. (2016). Indonesia penyumbang sampah plastik terbesar ke-dua dunia. CNN Indonesia. https://www.cnnindonesia.com/gaya-hidup/20160222182308-277112685/indonesia-penyumbang-sampah-plastik-terbesar-ke-dua-dunia

Yakusheva, V. V, Vasilenko, I. O., Mukhina, I. V, Kryakvina, E. A., \& Fomenko, A. V. (2017). Import substitution of raw resources as a stabilizing factor of meat industry. International Journal of Economic Perspectives, 11(2), 866-876. 